Macmillan

Master

Series

\title{
Work Out
}

\section{Biology}




\section{The titles \\ in this \\ series}

For examinations at $16+$

Biology

Chemistry

Computer Studies

English Language

French

German

Mathematics

For examinations at ' $A$ ' level

Applied Mathematics

Biology

Chemistry

English Literature

Physics

Pure Mathematics

Statistics
Physics

Principles of Accounts

Spanish

Statistics 


\section{MACMILLAN MASTER SERIES}

\section{Work Out}

\section{Biology}

'A' Level

G. W. Stout

and

N. P. O. Green

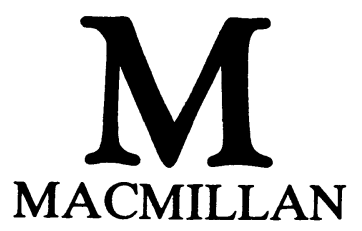


○ G. W. Stout and N. P. O. Green 1986

All rights reserved. No reproduction, copy or transmission of this publication may be made without written permission.

No paragraph of this publication may be reproduced, copied or transmitted save with written permission or in accordance with the provisions of the Copyright Act 1956 (as amended).

Any person who does any unauthorised act in relation to this publication may be liable to criminal prosecution and civil claims for damages.

First published 1986

Published by

MACMILLAN EDUCATION LTD

Houndmills, Basingstoke, Hampshire RG21 2XS

and London

Companies and representatives

throughout the world

Typeset by TecSet Ltd

British Library Cataloguing in Publication Data

Stout, G.W.

Work out biology : 'A' Level.-(Macmillan work out series)

1. Biology-Examinations, questions, etc.

I. Title II. Green, N.P.O.

574'.076 QH316

ISBN 978-0-333-39184-6 ISBN 978-1-349-07973-5 (eBook)

DOI 10.1007/978-1-349-07973-5 


\section{Contents}

Preface

Acknowledgements

Examining Boards for Advanced Level

viii

ix

ix

1 Introduction

1.1 How To Use This Book

1.2 Examinations and Assessment

1.3 Guide to Study and Revision

1.4 Examination Technique

1.5 Types of Questions

1.6 Terms Used In Examinations

2 Chemicals of Life

2.1 Basic Biochemistry

2.2 Organic Molecules

2.3 Enzymes

2.4 Worked Examples

20

22

3 Cytology and Histology

3.1 Cytosol

3.2 Cytoplasmic Organelles Common to Animal and Plant Cells

3.3 Structures Characteristic of Plant Cells

32

3.4 Plant Tissues

33

3.5 Animal Tissues

34

3.6 Worked Examples

4 Autotrophic Nutrition

4.1 Autotrophism

44

4.2 Photosynthesis

44

4.3 Leaf Structure

45

4.4 Chloroplasts

45

4.5 Photosynthetic Pigments and Light

45

4.6 'Light Reaction'

45

4.7 'Dark Reaction'

46

4.8 Limiting Factors

46

$4.9 \mathrm{C}_{4}$ Plants

46

4.10 Compensation Point 47

4.11 Experimental Investigations $\quad 47$

4.12 Chemoautotrophs $\quad 47$

4.13 Mineral Nutrition $\quad 47$

4.14 Worked Examples $\quad 48$

5 Heterotrophic Nutrition

5.1 Holozoic Nutrition

5.2 Digestion in Man

5.3 Saprophytic Nutrition

5.4 Symbiosis 
5.5 Parasitism 63

5.6 Worked Examples 63

6 Respiration and Gaseous Exchange

6.1 Energy 70

6.2 Respiration 71

6.3 Aerobic Respiration 71

6.4 Anaerobic Respiration 72

6.5 Mitochondria 72

6.6 Respiratory Quotient (RQ) 72

6.7 Gaseous Exchange 72

6.8 Gaseous Exchange Surfaces 73

6.9 Worked Examples 74

7 Transport

7.1 Transport in Plants $\quad 80$

7.2 Transport in Animals $\quad 83$

7.3 Worked Examples $\quad 87$

8 Plant Co-ordination

8.1 Plant Movements 101

8.2 Plant Growth 101

8.3 Plant Growth Regulator Substances 102

8.4 Flowering (a Photoperiodic Response) 105

8.5 Vernalization 105

8.6 Worked Examples 106

9 Animal Co-ordination

9.1 Co-ordinating Systems 113

9.2 Nervous Communication $\quad 113$

9.3 Receptors 116

9.4 Photoreception in the Eye 117

$\begin{array}{lll}9.5 & \text { Hearing } & 117\end{array}$

$\begin{array}{ll}9.6 \text { Balance } & 118\end{array}$

9.7 Chemical Communication 118

$\begin{array}{ll}9.8 \text { Worked Examples } & 119\end{array}$

10 Support and Movement

$\begin{array}{lll}10.1 & \text { Skeletal Structures } & 127\end{array}$

$\begin{array}{ll}10.2 \text { Muscle Systems } & 128\end{array}$

10.3 Worked Examples 130

11 Homeostasis

11.1 Control of Respiratory Gases in the Blood 135

11.2 Temperature Regulation 136

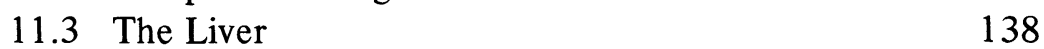

11.4 Worked Examples 139

12 Excretion and Osmoregulation

12.1 Significance of Excretion and Osmoregulation $\quad 144$

12.2 Excretory Products 145

12.3 Mammalian Kidney 145

12.4 Other Excretory Mechanisms 148

12.5 Excretion and Osmoregulation in Plants 149

12.6 Worked Examples 150

13 Reproduction

13.1 Asexual Reproduction 155 
14 Growth and Development

14.1 Measurement of Growth 168

14.2 Patterns of Growth 169

14.3 Growth and Development in Plants 169

14.4 Metamorphosis 171

14.5 Development in Vertebrates 171

14.6 Worked Examples 171

15 Chromosome Behaviour

15.1 Chromosome Structure 175

$\begin{array}{ll}15.2 \text { Mitosis } & 175\end{array}$

$\begin{array}{lll}15.3 \text { Meiosis } & 176\end{array}$

15.4 Chromosome Mutations 178

15.5 Gene Mutations 178

$\begin{array}{ll}15.6 \text { Worked Examples } & 179\end{array}$

16 Genetics

16.1 Mendel and His Work 186

16.2 Testcross 188

16.3 Linkage 188

16.4 Sex Determination 189

16.5 Sex Linkage 189

16.6 Incomplete Dominance 189

16.7 Multiple Alleles 189

16.8 Worked Examples 190

17 Evolution and Speciation

17.1 Evolutionary Theory 198

17.2 The Work of Charles Darwin 199

17.3 Evidence for Natural Selection 199

17.4 Evidence for Evolution 200

17.5 Modern Views on Evolution 202

17.6 Population Genetics 202

17.7 Selection 202

17.8 Natural Selection 203

17.9 Speciation 203

17.10 Worked Examples 204

18 Ecology

18.1 The Ecosystem 212

18.2 Biotic Components of an Ecosystem 213

18.3 Ecological Pyramids 213

18.4 Production Ecology 214

18.5 Ecological Succession 214

18.6 Zonation 215

18.7 Communities and Populations 215

18.8 Population Dynamics 215

18.9 Biogeochemical Cycles 216

18.10 Abiotic Components of the Ecosystem 216

18.11 Worked Examples 217

$\begin{array}{ll}\text { Index } & 225\end{array}$ 


\section{Preface}

The aim of this book is to help you to prepare for your ' $A$ ' level Biology examinations. In doing this, it differs from most other study guides and revision guides by giving you actual answers to questions rather than guidance as to how to approach the questions.

It has been the authors' experience as teachers and examiners that what examination candidates really need to see are actual answers. These answers are not to be taken as 'definitive' answers. They are not necessarily the only answers which could satisfactorily answer the questions. To this extent they are not to be considered as 'model' answers. At ' $\mathrm{A}$ ' level it is doubtful if there is such a thing.

Cambridge and Horsham, 1986

G.W.S.

N.P.O.G. 


\section{Acknowledgements}

Figure 6.1 by the late K. Murray is reproduced by kind permission of his wife.

The cover photograph, by Manfed Danegger NHPA, shows Anas platyrhynchos (mallard) taking off from a lake.

The authors and publishers also wish to thank the following who have kindly given permission for the use of copyright material:

The Associated Examining Board, the Joint Matriculation Board, the Northern Ireland Schools Examination Council, the Oxford and Cambridge Schools Examination Board, the Scottish Examination Board, the University of Cambridge Local Examinations Syndicate, the University of London Schools Examinations Board and the University of Oxford Delegacy of Local Examinations for questions from past examination papers.

Every effort has been made to trace all the copyright holders but if any have been inadvertently overlooked the publishers will be pleased to make the necessary arrangement at the first opportunity.

The University of London Entrance and School Examinations Council accepts no respons1bility whatsoever for the accuracy or method in the answers given in this book to actual questions set by the London Board.

Acknowledgement is made to the Southern Universities' Joint Board for School Examinations for permission to use questions taken from their past papers but the Board is in no way responsible for answers that may be provided and they are solely the responsibility of the authors.

The Associated Examining Board, the University of Oxford Delegacy of Local Examinations, the Northern Ireland Schools Examination Council, the University of Cambridge Local Examinations Syndicate and the Scottish Examination Board wish to point out that worked examples included in the text are entirely the responsibility of the authors and have been neither provided nor approved by the Board.

\section{Examination Boards for Advanced Level}

Syllabuses and past examination papers can be obtained from:

The Associated Examining Board

(AEB)

Stag Hill House

Guildford

Surrey GU2 5XJ

Joint Matriculation Board (JMB)

78 Park Road

Altrincham

Cheshire WA 14 5QQ
University of Cambridge Local Examination Syndicate (UCLES)

Syndicate Buildings

1 Hills Road

Cambridge CB1 2EU 
University of Oxford

Delegacy of Local Examinations (OLE)

Ewert Place

Summertown

Oxford OX2 7BZ

Scottish Examination Board (SEB)

Robert Gibson \& Sons (Glasgow) Ltd

17 Fitzroy Place

Glasgow G3 7SF

Welsh Joint Education Committee (WJEC)

245 Western Avenue

Cardiff CF5 2YX
Oxford and Cambridge Schools

Examination Board (O \& C)

10 Trumpington Street

Cambridge CB2 1QB

\section{Southern Universities, Joint Board} (SUJB)

Cotham Road

Bristol BS6 6DD

Northern Ireland Schools Examination Council (NISEC)

Examinations Office

Beechill House

Beechill Road

Belfast BT8 4RS 